\title{
VÝSKUM HRADU DOBRÁ NIVA V ROKOCH 2013 A 2014
}

\author{
NOÉMI BELJAK PAŽINOVÁ - JÁN BELJAK - MICHAL ŠIMKOVIC
}

\begin{abstract}
Abstrakt: Ciel'om príspevku je predstavit' a interpretovat' nálezovú situáciu na NKP Hrad Dobrá Niva v katastrálnom území obce Podzámčok, okres Zvolen. Archeologický výskum uskutočnený v rokoch 2013 a 2014 priniesol nové informácie o vrcholno- a neskorostredovekom až novovekom hrade Dobrá Niva z hladiska materiálnej kultúry i stavebno-konštrukčnom vývoji hradného paláca a predhradia. Deštruktívny i nedeštruktívny archeologický výskum hradu, kombinovaný so štúdiom prameňov, pomohol k spresneniu pôdorysu hradného paláca a poznaniu doteraz neznámych prestavieb. Doplnené boli zároveñ aj údaje o chronológii osidlenia a existencii drevenej palisády v blizkosti terénnej hrany vo východnej časti predhradia.
\end{abstract}

Kl'účové slová: Dobrá Niva hrad - archeologický výskum - terénna situácia - vrcholný a neskorý stredovek-včasný novovek.

\section{Research into the Dobrá Niva Castle in 2013-2014}

Abstract: This contribution sets out to present and interpret the context of excavations at the Dobrá Niva castle, a national cultural monument, in the cadastral zone of the Podzámćok village, Zvolen district. Archaeological research conducted in the years 2013 and 2014 brought new information about the high and late medieval - early modern age castle as regards its material culture and the building development of the palace and the bailey. Destructive and non-destructive archaeological research of the castle combined with the study of sources helped specify the ground plan of the palace and identify hitherto unknown reconstructions. At the same time, information about the settlement chronology and the existence of a wooden palisade near the geological fault in the eastern section of the bailey was expanded.

Key words: Dobrá Niva castle - archaeological research - historical context - high and late Middle Ages early modern age.

Obec Dobrá Niva v okrese Zvolen sa nachádza na strednom Slovensku v strednej časti Pliešovskej kotliny. Hrad s eponymným názvom je situovaný na homol’ovitej vyvýšenine (obr. 1) severne od obce vo vzdialenosti necelé $3 \mathrm{~km}$ vzdušnou čiarou na pravej strane cesty zo Šiah (Krupiny) do Zvolena. Zrúcanina patrí do katastra obce Podzámčok, ktorá sa vyvinula z majera pod hradom. Hrad Dobrá Niva bol vyhlásený za národnú kultúrnu pamiatku v roku 1963 (číslo v Ústrednom zozname pamiatkového fondu je 1110/1).

Výskumné aktivity sa na hrad sústredili v roku 2013, ked' výkopy realizoval Archeologický ústav SAV, pracovisko Zvolen, a v roku 2014, ked' sa archeologický výskum uskutočnil pod záštitou Katedry archeológie FF UKF v Nitre. Architektonicko-historické vyhodnotenie odkrytých murív spracoval M. Šimkovic.

Ciel’om výskumu bolo poznanie stavebnej dispozície a konštrukčného vývoja hradného paláca, d’alej spôsoby využitia a funkčné členenie predhradia, a to ako k sídelným účelom, tak aj k d’alším obranným, poprípade výrobným aktivitám v priebehu času.

\section{Popis hradu}

Hrad Dobrá Niva vznikol pri dôležitej obchodnej ceste Via Magna, ktorá v stredoveku spájala Uhorsko s Pol'skom, resp. Krakov s Budínom. Vybudovaný bol na kužel’ovitom návrší s výhl’adom na dlhý úsek údolia Neresnice so spomenutou obchodnou cestou. Podl'a zachovaných architektúr a terénnych reliktov mal hradný areál dvojdielnu dispozíciu približne oválneho pôdorysu s rozmermi ca $80 \times 90 \mathrm{~m}$. Na vrchole návršia bolo malé hradné jadro, dosahujúce vonkajšie rozmery približne $25 \times 20 \mathrm{~m}$. Z jeho architektúr sa nad terénom zachovala len čast' vonkajšej obvodovej steny paláca s pozostatkami arkiera a okenných otvorov troch podlaží. Hradné jadro koncentricky obklopovalo predhradie. Priebeh jeho opevnenia naznačuje konfigurácia 


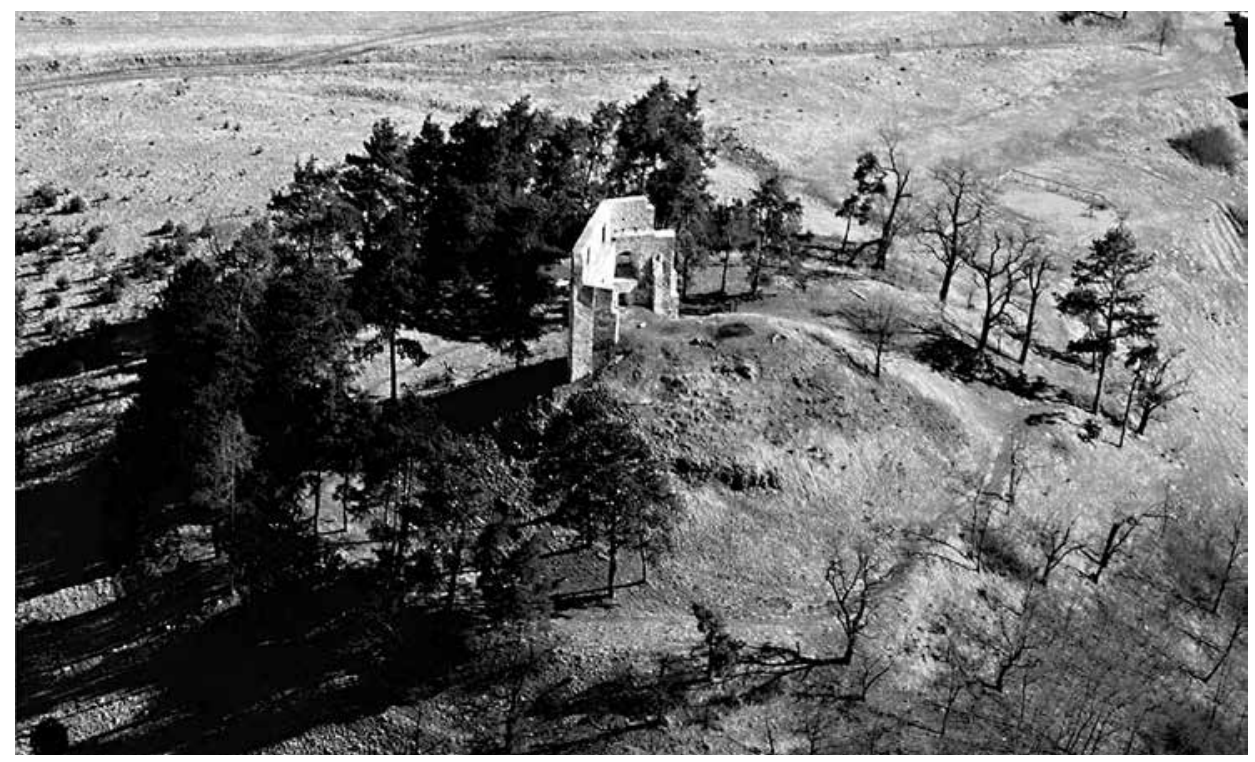

Obr. 1. Národná kultúrna pamiatka Hrad Dobrá Niva, okr. Zvolen, na leteckej snímke z roku 2011. Foto J. Beljak. Abb. 1. Nationales Kulturdenkmal Burg Döbring, Bezirk Zvolen, auf einer Luftaufnahme von 2011. Foto J. Beljak.

terénu a ojedinelý fragment múru na južnej strane, ktorý môže byt' zvyškom vstupnej brány. V teréne sa na juhovýchodnej strane rysuje aj priebeh prístupovej cesty s jej vyústením k predpokladanej hradnej bráne. Oproti prístupu je opevnenie predhradia na vonkajšej strane zosilnené drevozemným valom (miestami i dvojitým) a priekopou.

\section{Dejiny bádania}

Najstaršiu známu dokumentáciu zvyškov hradu publikoval v roku 1859 F. Kubínyi $(1859,31)$. Spomína na akropole sutovým zásypom zapadnuté a vegetáciou zarastené priestory, z ktorých rozmiestnenia už vôbec nie je jasné, či mal hradný palác šest’uholníkovú alebo až osemuholníkovú dispozíciu. F. Kubínyi spracoval aj náčrt pôdorysu paláca, kde naznačil šest'uholníkový tvar.

Prvé celkové zameranie celého hradného areálu spájame s Š. Janšákom (1930, 60-61, tab. XVII), ktorý verne zachytil celý areál hradu s vonkajším opevnením. Zvyšky paláca sú však zakreslené pomerne schematicky.

Ruinu hradu dokumentovala aj česká bádatel'ka D. Menclová. V jej pozostalosti (v Archíve Národného múzea Praha, fond Menclovi) je uložená skica pôdorysu jadra so zachovanými zvyškami suterénnych priestorov na západnej strane.

Začiatkom 90. rokov minulého storočia uskutočnil terénny prieskum hradu a celkové zameranie M. Šimkovic (obr. 2). V roku 1996 bola realizovaná pamiatková obnova, ktorá výrazne zasiahla do podoby jedinej zachovanej steny hradného paláca. V rámci týchto aktivít bola realizovaná aj archeologická obhliadka miesta a identifikované boli sporadické keramické i kovové nálezy zo 17. a 18. storočia (Malček 1997, 133).

\section{Historické pramene k dejinám hradu}

Najnovšie sa stredovekými dejinami Dobrej Nivy zaoberal P. Maliniak (2014, 54-56, tu aj bližšia literatúra). Prvá písomná zmienka o obci Dobrá Niva pochádza od krála Bela IV. z roku 1254, v ktorej potvrdzuje mestské práva a slobody Dobrej Nive i Babinej. Hrad sa prvýkrát 


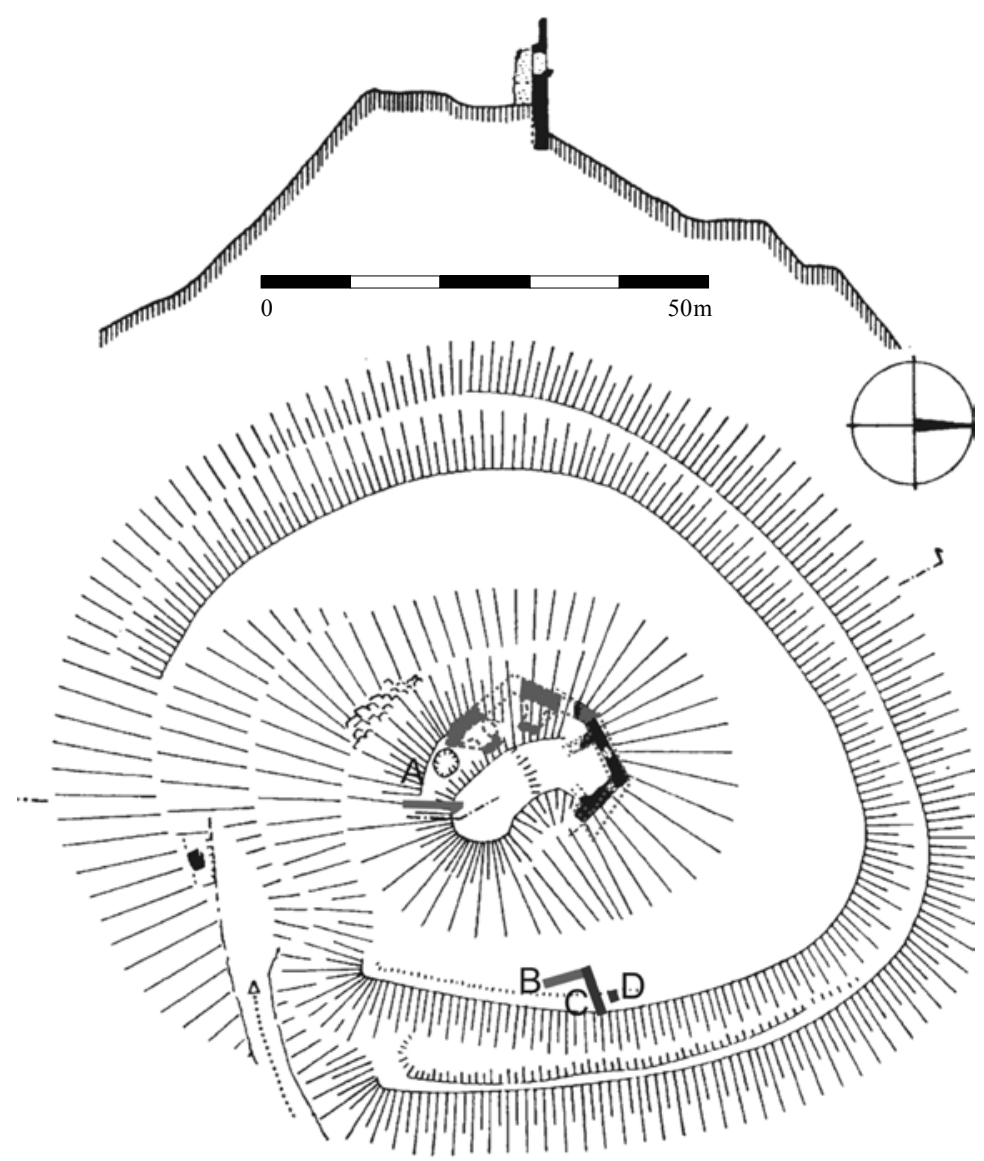

Obr. 2. Hrad Dobrá Niva, okr. Zvolen. Pôdorys a profil hradného návršia podl’a M. Šimkovica (čierna farba) z roku 1995 a podl’a D. Menclovej (šedá farba) z polovice 20. storočia. Realizované archeologické sondy: A - sonda 1/2013, B - sonda 2/2013, C - sonda 1/2014, D - sonda 1A/2014.

Abb. 2. Burg Döbring, Bezirk Zvolen. Grundriss und Profil des Burghügels nach M. Šimkovic (schwarz) aus dem Jahr 1995 und nach D. Menclová (grau) aus der Mitte des 20. Jhdts. Archäologische Sondiergrabungen: A - Sondierschnitt 1/2013, B - Sondierschnitt 2/2013, C - Sondierschnitt 1/2014, D - Sondierschnitt 1A/2014.

spomína v listinách v roku 1306, ked’ vojsko nastupujúceho uhorského krála Karola Róberta vydobylo Dobronivský hrad spolu s d’alšími pevnost’ami od zvolenského župana Demetera. V roku 1337 prvýkrát nachádzame Dobronivský hrad pod názvom Dobraniua a za podkastelána hradu je titulovaný Ondrej z Lánca. O zdržiavaní sa aj králov na Dobronivskom hrade svedčia královské listiny vydané „, in Dobronya“ v roku 1377 L’udovítom I. a v roku 1404 králom Žigmundom. Mocenské zápasy po smrti Žigmunda v polovici 15. storočia v regióne vyvrcholili do porušovania práv mestečka úradníkmi na Dobronivskom hrade. Dozvedáme sa o tom na základe nariadenia uhorského král'a Ladislava Pohrobka z roku 1454, kde dobronivským kastelánom zakazuje zasahovat' do záležitostí Dobrej Nivy, Babinej a Sásy.

Počas krála Mateja Korvína hrad zmenil viacerých majitelov. Najprv král' potvrdil držbu hradu a panstva rakúskemu šlachticovi a vojenskému velitel'ovi Ondrejovi Baumkircherovi, ktorému dal hrad do zálohu v roku 1455 ešte Ladislav Pohrobok. Následne v roku 1464 král' Matej udelil Dobronivské panstvo svojmu pokladníkovi Benediktovi z Turca. Neskôr viaceré hradné panstvá, medzi nimi aj Dobronivské, venoval král' svojej manželke Beatrix Aragónskej. Tá v roku 1486 udelila hrad s panstvom za 7000 zlatých do zálohu chorvátskemu šlachticovi Bernardovi Frangepanovi a jeho rodine. Ten hrad s panstvom v roku 1515 daroval pri príležitosti 
sobáša svojej dcére Ižote. Jej manžel v roku 1518 vymenil celé panstvo za iné majetky s král’ovským úradníkom a dvoranom Štefanom Werbőczym, ktorý sa na hrade opakovane zdržiaval $\mathrm{v}$ roku 1526.

Novoveké dejiny Dobronivského hradu a panstva spracovali viacerí bádatelia (Slávik 1898; Gindl 1967; Maliniak 2014a). Spomenút' treba hlavne posledného majitel'a - rodinu Esterházi, ktorá sa k hradu dostala začiatkom 17. storočia. Roku 1638 zvolenské a dobronivské panstvo po zložení sumy 133000 zlatých dostal do vlastníctva barón Pavol Esterházi (1587-1645), zakladatel' zvolenskej línie rodu s predikátom z Galanty. Až do roku 1710 sú ako vlastníci zámku uvedení Mikuláš (1634-1681), zvolenský župan a Alexander, synovia Pavla Esterházi, potom Štefan a Wolfgang Esterházi a ich sestry Agnesa Forgáč (Forgach) a Katarína Penej (Penyey).

Následne je zámok podl'a majetkových súpisov Dobronivského panstva z roku 1710 už opustený a spôsobuje len výdavky. Zlý stav potvrdzuje aj Matej Bel v druhom diele svojich Notitia Hungariae novae historico-geographica z roku 1736 v časti Comitatus Zoliensis (Zvolenská stolica) pod názvom De Arce Dobroniwa, ked' o hrade hovorí ako o opustenom s popraskanými múrmi.

Na stave hradu sa zrejme podpísali aj živelné pohromy, ktoré túto oblast' postihli: zemetrasenie 16. septembra 1614, silná víchrica 21. decembra 1740 a d’alšie zemetrasenie 28. júna 1763. Hoci sa o tom písomné pamiatky nenašli, tieto pohromy nepochybne postihli aj hrad. Na mape 1. vojenského mapovania územia Uhorska z rokov 1782-1784 je pri ňom už uvedené: „ruiny starého dobronivského hradu“. Obnove hradu zrejme nepomohla ani tehel'ňa v Podzámčoku, o ktorej vybudovaní rozhodla zemepánska aj Zvolenská stolica (Maliniak 2014a, 63).

Podobu hradu poznáme zo 17. storočia, ked’ ho znázorňujú dve veduty. Prvá od J. Ledentu z roku 1639 s názvom DOBRA (Kopčan-Krajčovičová 1983, 127). Druhá od utrechtského rytca a kresliara Justusa van der Nypoort, ktorá je uverejnená v učebnici geometrie Ernsta Burcharda von Birkenstein, prvýkrát vydanej vo Viedni v roku 1686 (Závadová 1974, obr. 109, 110). Tento obrázok však nekorešponduje s jeho zachovaným popisom z roku 1668. Na rytine je totiž znázornených ovel'a viac budov a aj opevnenie je ovel'a rozsiahlejšie, ako uvádza popis hradu, čo vzbudzuje pochybnosti o hodnovernosti rytiny, resp. na obrázku je zrejme vyobrazený iný hrad s názvom Dobra.

Pomerne detailný popis hradu sa zachoval od jeho vtedajšieho majitel’a Alexandra Esterháziho v urbáre s názvom Urbarium z roku 1668 (Knauz-Nagy 1862, 466). Podl’a neho sa hrad skladal z väčšej a menšej brány, dvojposchodovej budovy paláca a bašty. Na prízemí paláca sa nachádzalo devät' miestností: predsieň, izba drába a d’alších sedem klenutých oblúkových miestností. V jednej z nich bola studňa (cisterna?). Prvé poschodie malo osem miestností a vonkajšia chodba viedla do d’alších troch miestností. Na druhom poschodí sa nachádzala predsieň a dve miestnosti. Z predsiene sa vychádzalo na strechu budovy. Pod strechou, krytou šindlom, bolo d’alších sedem malých miestností.

Uvedený popis nás zrejme informuje iba o budove samotného paláca. Okrem miestností uvedených $\mathrm{v}$ popise museli však nepochybne na hrade existovat' ešte hospodárske budovy. Tieto však predstavený dokument nespomínal.

\section{Moderný archeologický výskum hradu}

V rokoch 2013 a 2014 boli formou kombinovaného zistovacieho výskumu realizované archeologické sondáže a prieskumy na lokalite. Išlo o kombináciu nedeštruktívnych foriem výskumu (letecký prieskum a geofyzikálna prospekcia) a terénnych archeologických výkopov na hradnom jadre (sonda 1/2013) a predhradí (sonda 2/2013, 1/2014 a 1A/2014).

\subsection{Geofyzikálny výskum}

Zámerom geofyzikálneho výskumu bolo zistit' rozsah a híbku tvrdých materiálov (kamenný stavebný materiál, sutinové zásypy a pod.) alebo dutých priestorov na nádvorí a na akropole 
hradu, ako aj nadobudnút' informácie o ich orientácii voči svetovým stranám a rozmeroch. Mimoriadny dôraz sa kládol na určenie stavebnej dispozície hradného paláca, teda či ide o šest'hran alebo osemhran. Výsledky meraní, realizované J. Tirpákom z Gemologického ústavu Univerzity Konštantína Filozofa v Nitre, poukázali na niekol'ko anomálií, ktoré môžu indikovat' zvyšky súvisiace s kamennými základmi, prípadne so sutinovým zásypom. Geofyzikálne meranie na hradnom jadre potvrdilo šest'uholníkový pôdorys obvodového plášt’a hradného paláca. Vo východnej časti predhradia síce neboli zistené stopy po možných kamenných fortifikačných prvkoch, ale namerané georadarové anomálie v priestore sond 2/2013 a 1/2014 poukázali na možné fragmenty stavebných materiálov, prípadne architektonických zvyškov, nachádzajúcich sa pod povrchom skúmaného terénu. $Z$ dôvodu overenia týchto skutočností, prípadne potvrdenia objektov vyplnených kamennou deštrukciou, sme pristúpili k sondážnemu archeologickému výskumu.

\subsection{Sondážny zist'ovací výskum}

\subsubsection{Hradné jadro - popis a interpretácia terénnej situácie}

Hradné jadro (akropola) bolo skúmané archeologickou sondou (sonda 1/2013) umiestnenou na južnom bočnom svahu vrcholovej plošiny. Jej rozmery boli pôvodne $1 \times 9 \mathrm{~m}$, po jej rozšírení v severnej časti na šírku 1,5-1,8 $\mathrm{m}$ dosiahla prekopaná plocha $10,5 \mathrm{~m}^{2}$. Cielom výkopu bolo zistenie polohy, založenia a zachovanej výšky južného obvodového múru hradného paláca. V sonde sme objavili murovanú architektúru z dvoch až troch rôznych stavebných etáp hradu (obr. 3). V celej južnej časti sondy bol odkrytý mohutný obvodový múr, prebiehajúci šikmo voči sonde (v smere severovýchod-juhozápad). V ňom boli zistené dve etapy výstavby (obr. 3:M1, M2), ktoré sú od seba oddelené pozdížnou cezúrou. Ako staršie sa javí vyššie položené murivo (M1) so zachovaným vonkajším lícom. Naň nadväzuje jadro muriva, zachované v maximálnej šírke 1,3 m od líca. Na vnútornej (severnej) strane je murivo deštruované. Líce múru sa nepodarilo odkryt'. Táto vnútorná deštruovaná čast' múru sa javila ako prekrytá vrstvou hlinitej dlážky, zistenej v sonde (obr. 3:C).

K vonkajšiemu lícu staršieho muriva je na vonkajšej strane dodatočne pristavaný mladší múr, široký 2,1 m (obr. 3:M2). Pôvodné vonkajšie líce múru, zachované do výšky ca $0,5 \mathrm{~m}$, bolo odkryté v rámci východného profilu sondy.

Z chronologického hl'adiska sa ako najmladšie javí líce steny (obr. 4) zistené v hornej (severnej) časti sondy a prebiehajúce vo forme priečky približne kolmo na spomenutý obvodový múr (obr. 3:M3). Na severozápadnej strane je do neho primárne osadená spodná čast' ostenia gotického portálu (obr. 3:A). Ostenie pozostávajúce z dvoch segmentov je profilované širokým skosením hrany, ktorá na spodnej strane prechádza do plnej pätky ihlanovým nosíkom. Podla orientácie zachovaného ostenia je možné predpokladat', že portál viedol do miestnosti, ktorá sa nachádzala mimo plochy sondy severovýchodným smerom. Líce steny, v ktorej bol portál osadený, sa zachovalo v dížke 2,1 m juhovýchodným smerom od ostenia a ukončené bolo približne zvislou deštrukciou.

Okrem murív bol v sonde odkrytý architektonický článok. Tvorí ho torzo konzoly (obr. 3:B), z ktorej sa zachovala nahrubo opracovaná čast' uložená pôvodne do steny. Vonkajšia nosná čast' konzoly je odlomená. Konzola je na spodnej strane zaoblená a profilovaná skosením spodných hrán.

Výskum v sonde 1/2013 priniesol nové poznatky o prestavbách hradu v stredoveku. V kontexte celkovej dispozície a vývoja hradu je možné najstarší múr (M1) považovat’ za zvyšky juhovýchodného úseku obvodovej hradby hradného jadra. Múr mal hrúbku minimálne 1,3 m, jeho celkovú šírku sa pre deštrukciu vnútorného líca nepodarilo zistit'. Pôvodný múr bol z vonkajšej strany dodatočne obstavaný mladším masívnym múrom (M2), širokým 2,1 m. Jeho vznik pravdepodobne súvisí so zánikom pôvodnej hradby, pričom vonkajší múr prebral jeho funkciu opevnenia a došlo k rozšíreniu plochy jadra. K tejto hradbe bola $\mathrm{z}$ vnútornej strany pristavaná stavba, z ktorej sa podarilo odkryt' juhozápadnú obvodovú stenu alebo priečku so vstupným portálom 


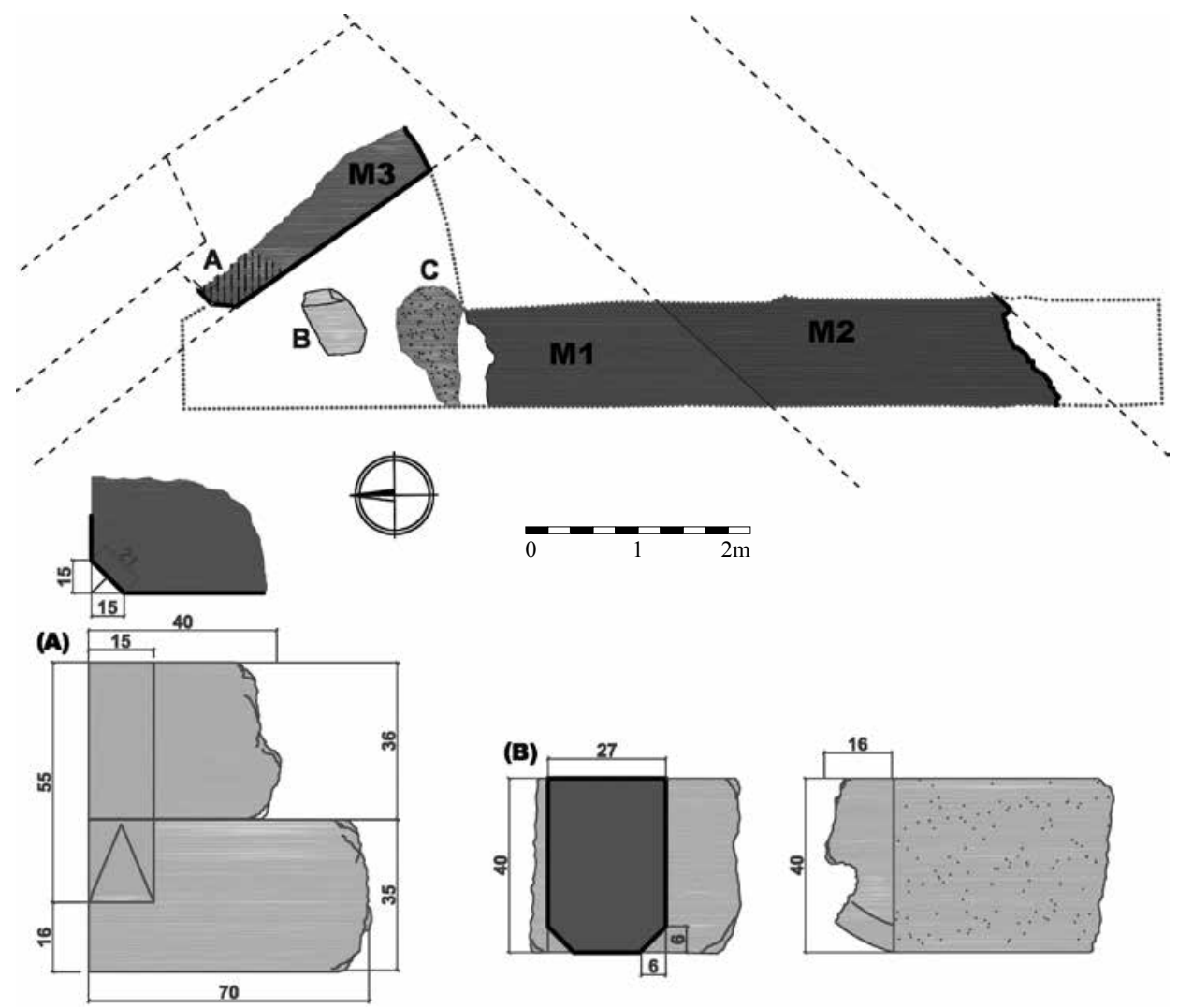

Obr. 3. Hrad Dobrá Niva, okr. Zvolen. Pôdorys sondy 1/2013 na akropole a jej architektonicko-historická interpretácia: M1 - gotika, pravdepodobne 14. storočie, M2 - gotika, koniec 14. až 15. storočie, M3 - gotika, koniec 14. až 15. storočie; A - ostenie portálu, B - konzola, C - hlinená podlaha. Kresba M. Šimkovic.

Abb. 3. Burg Döbring, Bezirk Zvolen. Grundriss von Sondierschnitt 1/2013 auf dem Burgberg und seine bauhistorische Interpretation: M1 - Gotik, wahrscheinlich 14. Jhdt., M2 - Gotik, Ende 14. bis 15. Jhdt., M3 - Gotik, Ende 14. bis 15. Jhdt.; A - Laibung des Portals, B - Konsole, C - Lehmfußboden. Zeichnung M. Šimkovic.

(M3). Celkové proporcie zachovanej časti ostenia spolu s profiláciou širokým skosením hrany naznačujú, že otvor mal pomerne vel'kú svetlú šírku. Hoci napojenie steny s portálom na obvodovú hradbu nebolo preskúmané, je možné, že je súčasná s mladším murivom obvodovej hradby (M2). Zároveň je zjavné, že najneskôr pri vzniku budovy s portálom došlo k zbúraniu najstaršieho múru (M1). Jeho priebeh a poloha sa so spomenutou stenou s portálom priestorovo vylučujú.

Z hl’adiska časového zaradenia jednotlivých murív predstavuje jediný datovatelný prvok ostenie odkrytého portálu. Na základe ihlanového ukončenia profilácie je možné portál a zvyšky budovy zaradit' do konca 14. alebo 15 . storočia. S ním je zrejme súčasná aj mladšia hradba. Z toho vyplýva, že staršie murivo je možné s vel'kou pravdepodobnost'ou datovat' už do 14 . storočia, pričom nie je vylúčené, že ide o hradbu pôvodného hradu.

V sonde 1/2013 nebol objavený hnutel'ný archeologický materiál. Jediný nevýrazný novoveký črep bol zachytený v stavebnej suti.

\subsubsection{Predhradie-popis a interpretácia terénnej situácie}

Pre archeologické skúmanie predhradia bola vybraná sondážna metóda odkryvu s vytýčením celkovo troch archeologických sond.

Sonda 2/2013 bola orientovaná v severojužnom smere s rozmermi $1 \times 5 \mathrm{~m}$ (obr. 5). Odkrývaná bola postupne, $v$ desat'- až pätnást'centimetrových úrovniach, až na skalné podložie. Jej 


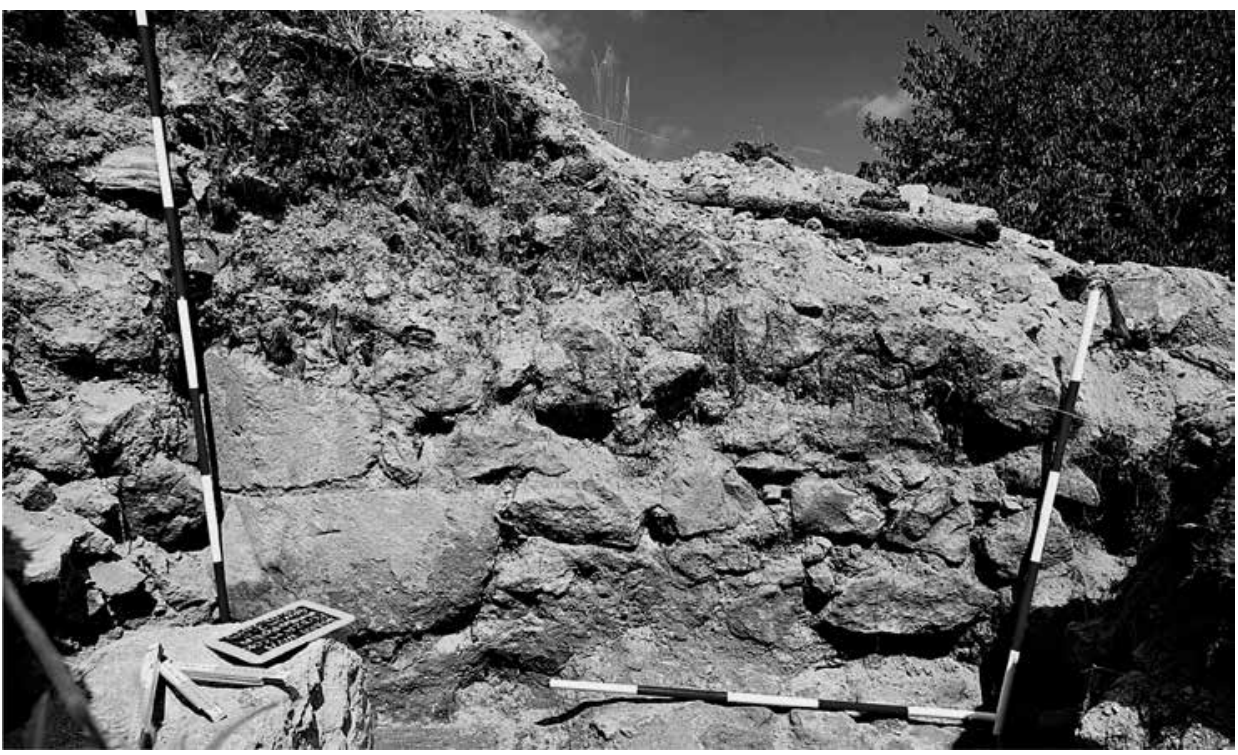

Obr. 4. Hrad Dobrá Niva, okr. Zvolen. Predhradie - líce steny M3 zistené v hornej (severnej) časti sondy 1/2013. Foto J. Beljak. Abb. 4. Burg Döbring, Bezirk Zvolen. Vorburg - Flucht der im oberen (nördlichen) Teil von Sondierschnitt 1/2013 entdeckten Wand M3. Foto J. Beljak.

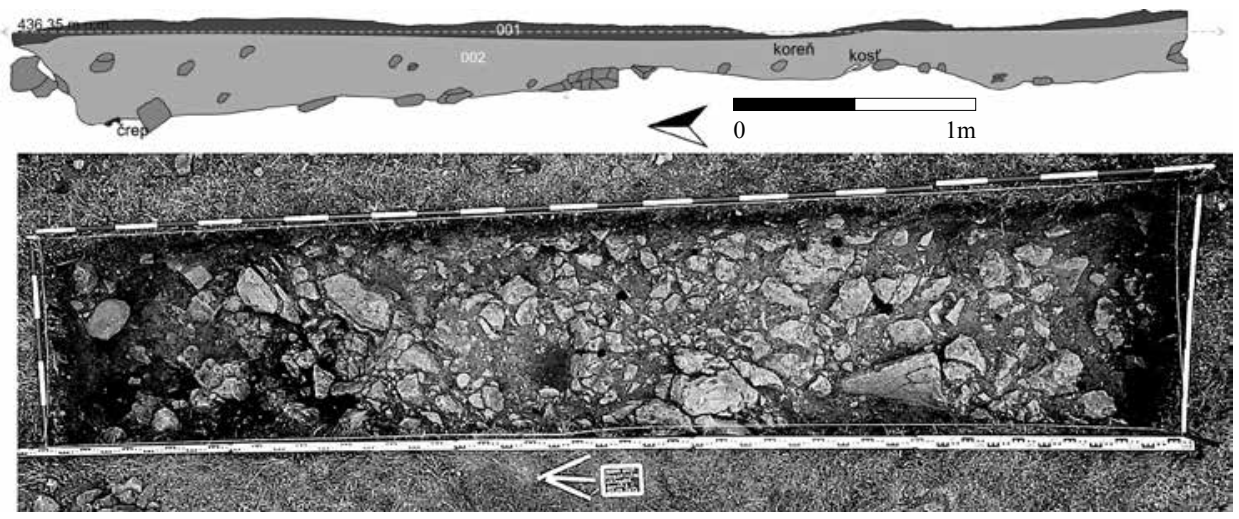

Obr. 5. Hrad Dobrá Niva, okr. Zvolen. Predhradie - pôdorys a východný profil sondy 2/2013. Foto a kresba N. Beljak Pažinová. Abb. 5. Burg Döbring, Bezirk Zvolen. Vorburg - Grundriss und Ostprofil von Sondierschnitt 2/2013. Foto und Zeichnung N. Beljak Pažinová.

výplň tvorili tri vrstvy. Na povrchu sa nachádzala šedohnedá humusová pôda (vrstva 001), ktorej mocnost' dosahovala $0,02-0,05 \mathrm{~m}$. Pod ňou bola situovaná tmavohnedá kultúrna vrstva (002), v ktorej sa nachádzali početné keramické zlomky, kovové predmety, zvieracie kosti a ojedinele aj drobné uhlíky. Na kompaktné šedé skalné podložie sa podarilo dokopat' v híbke $0,2-0,48 \mathrm{~m}$. V nálezovom súbore výrazne prevládal novoveký keramický materiál (vyše 1400 fragmentov) a zvieracie kosti (461 kusov). V menšom množstve sa objavili kachlice (11 ks), sklo, resp. spečená sklovitá hmota $(5 \mathrm{ks})$, kovové $(147 \mathrm{ks})$ a kostené $(5 \mathrm{ks})$ predmety, troska $(27 \mathrm{ks})$ a fragment taviaceho téglika.

Sonda 1/2014 bola orientovaná v západo-východnom smere, kolmo na sondu 2/2013. Jej rozmery boli $1 \times 7,5 \mathrm{~m}$ a odkrývaná bola $\mathrm{v}$ desat'- až pätnást'centimetrových úrovniach, až na 

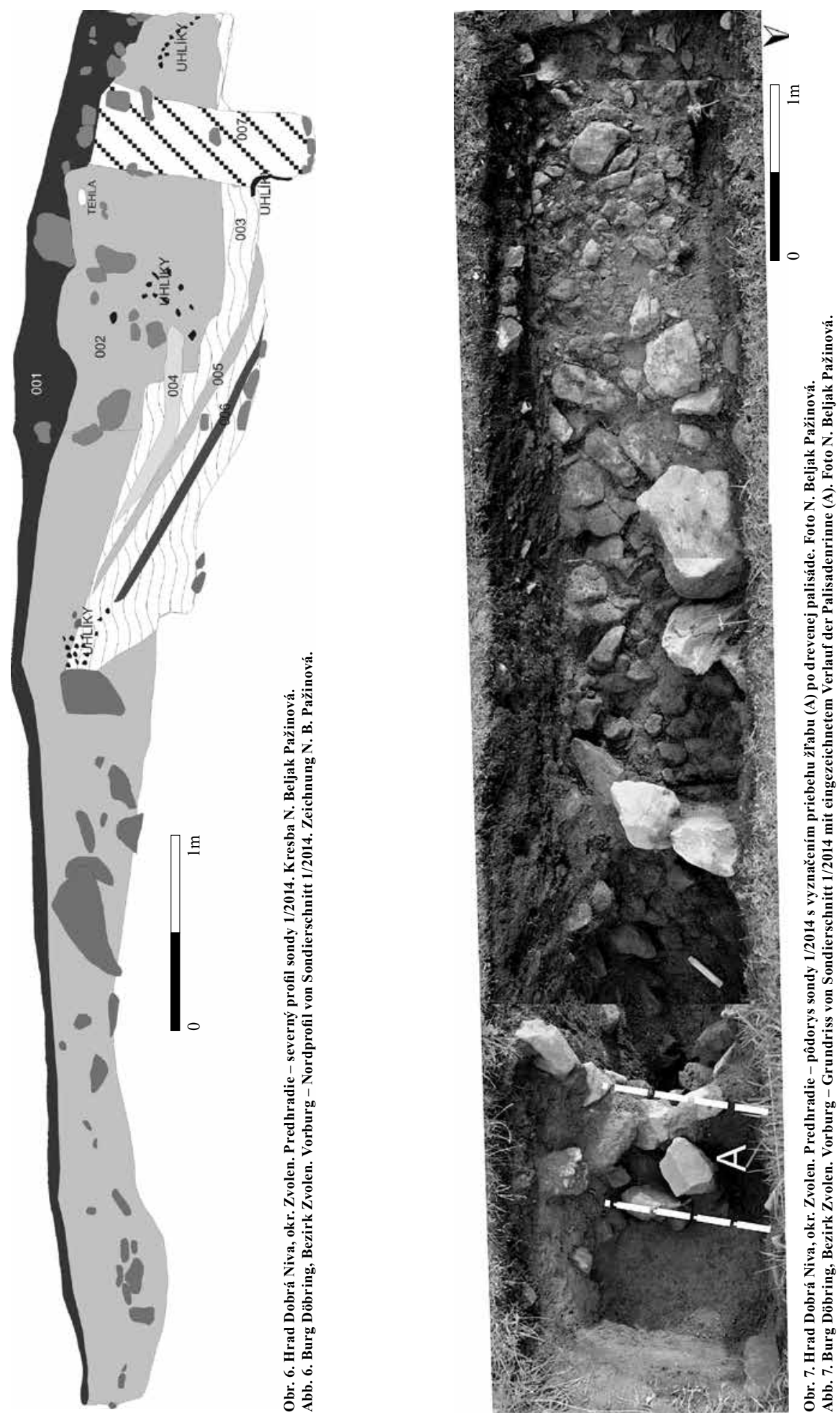


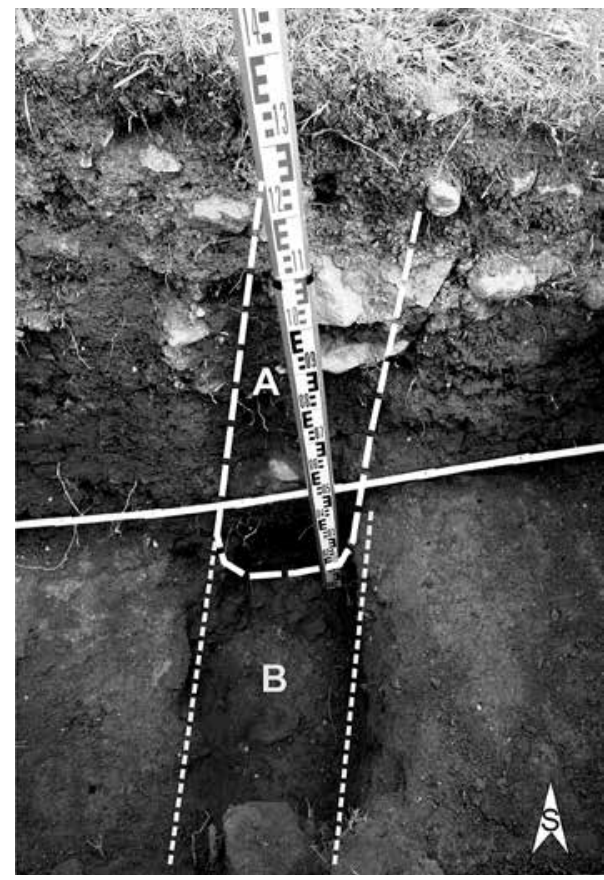

Obr. 8. Hrad Dobrá Niva, okr. Zvolen. Predhradie - fotografická dokumentácia detailu severného profilu sondy 1/2014 v mieste pôvodnej drevenej palisády, ktorá obklopovala predhradie z východu: A - vertikálna stopa po kole v profile, B - žl'ab po palisáde v pôdoryse. Foto N. Beljak Pažinová.

Abb. 8. Burg Döbring, Bezirk Zvolen. Vorburg - Fotodokumentation eines Details des Nordprofils von Sondierschnitt 1/2014 an der Stelle der ursprünglichen Holzpalisade, welche die Vorburg von Osten umgab: A - vertikale Spur eines Pfahls im Profil, B - Palisadenrinne im Grundriss. Foto N. Beljak Pažinová. kompaktné sterilné podložie. V západnej časti sondy, v úseku $1-4,5 \mathrm{~m}$ sa skalné podložie objavilo v max. híbke $0,25-0,6 \mathrm{~m}$ a boli tu zachytené rovnako ako $v$ sonde 2/2013 tri vrstvy výplne (humusová vrstva - 001, kultúrna vrstva - 002, skalné podložie). Vo východnej časti sondy v blízkosti terénnej hrany predhradia, v úseku 4,2-7,4 m bola výrazne odlišná terénna situácia. Dno sa v sonde náhle prehíbilo ostrým skokom úpravou/zasekaním do skalného podložia o približne $0,4 \mathrm{~m}$ (v tejto časti v profile zachytená výrazná vrstva prepálených uhlíkov) a následne klesalo postupne až do max. híbky $1,5 \mathrm{~m}$. Hlavne $\mathrm{v}$ severnom profile (obr. 6) boli zachytené v úseku 5-6m sondy viaceré tenšie i hrubšie plynule klesajúce pásy/vrstvy výplne, miestami premiešané aj s väčšími kúskami prepálených uhlíkov. Najhrubšiu spodnú vrstvu (003) tvorila kompaktná žltohnedá ílová výplň. Nad ňou (a čiastočne i s ňou premiešané) sa nachádzali početné nálezy spolu s napadanými kameňmi, súvrstvím sutiny s maltovinou $(004,005)$ i zvyškami tehloviny a tenšími medzivrstvami s uhlíkmi (006). Ílová výplň siahala až po upravené - zrejme intencionálne zarovnané kamenné podložie. Všetky vrstvy výplne sondy viditel'ne klesali až k profilovanému žlabu po drevenej palisáde, ktorý bol zachytený na max. dne sondy v úseku 6,1-6,45 m (obr. 7). $\mathrm{V}$ žltohnedom ílovom profile po oboch stranách sondy boli $\mathrm{v}$ tomto mieste vo výške ca 1,1-1,15 m zretel'ne viditel'né stopy (007) po vertikálnych (v hornej časti jemne východným smerom naklonených) koloch (obr. 8). Žlab mal pomerne rovné dno, ktoré malo šírku 0,35$0,4 \mathrm{~m}$. Dno žlabu zasahovalo do upraveného kamenného podložia, ktoré sa tu nachádzalo v híbke ca 1,4-1,5 m. Východný koniec sondy bol vyplnený kompaktným žltohnedým ílom.

Sonda obsahovala početný nálezový materiál, ktorý pozostával z 2275 ks keramických črepov (okrem včasnonovovekého materiálu boli medzi nimi sporadicky zastúpené aj praveké a vrcholnostredoveké fragmenty), 1045 ks zvieracích kostí, 92 ks kovových predmetov, 15 fragmentov skla, 8 fragmentov kachlíc, železnej trosky a kúskov spečenej sklovitej hmoty, ako aj z d’alších drobných hlinených a kostených predmetov.

Aby sme jednoznačne potvrdili existenciu drevenej palisády a jej d’alšie pokračovanie, otvorili sme severne od sondy 1/2014 menšiu kontrolnú sondu 1A/2014, ktorá bola od nej vzdialená $0,8 \mathrm{~m}$.

Sonda 1A/2014 mala rozmery $0,8 \times 1,2 \mathrm{~m}$ a bola vykopaná do híbky $0,6 \mathrm{~m}$, teda na takú úroveň, kde boli v pôdoryse i profiloch jednoznačne farebne odlíšitel’né stopy (hrúbka $0,4 \mathrm{~m}$ ) po drevenej palisáde, resp. drevených koloch, zachytené v žltohnedej ílovej výplni. Hoci sonda nebola plošne rozsiahla ani hlboká, obsahovala väčší počet novovekých nálezov: 197 ks keramiky, 38 ks kovových predmetov, 137 ks zvieracích kostí a jednu kachlicu. 


\section{Vyhodnotenie a záver}

Naše vedomosti o hrade Dobrá Niva pred realizovaním moderného archeologického výskumu vychádzali z písomných prameňov a interpretácie zachovaných nehnutel’ných reliktov. $\mathrm{Na}$ ich základe bolo možné predpokladat' intenzívnu činnost' $\mathrm{v}$ areáli počas vrcholného a neskorého stredoveku, pričom výrazné stavebné aktivity sa na hrade zrejme realizovali v období renesancie. Koncom 17. storočia, prípadne v priebehu prvej polovice 18. storočia majitelia a užívatelia hrad postupne opustili a objekt začal pustnút'.

Archeologický výskum NKP Dobrá Niva, realizovaný počas dvoch výskumných sezón celkovo na ploche o vel'kosti $24 \mathrm{~m}^{2}$, kombinovaný so štúdiom prameňov, pomohol k spresneniu pôdorysu hradného paláca a poznaniu jeho doteraz neznámych prestavieb, ako aj k identifikovaniu palisádového opevnenia východnej časti predhradia. Jednoznačne sa preukázalo, že hradný palác mal šest'hranný pôdorys a zachytená bola aj jeho staršia stavebná fáza siahajúca až do 14. storočia, pričom nie je vylúčené, že ide o murivo pôvodného paláca. Vo východnej časti predhradia sa archeologickým výskumom podarilo dokázat' a zdokumentovat' priebeh palisádového opevnenia areálu. Jeho vybudovanie si vyžiadalo cielené terénne úpravy pozostávajúce z vysekania a následného zarovnania skalného brala. Vzniknutý priestor bol vyplnený tvrdým žltohnedým ílom, do ktorého bola osadená mohutná palisáda. O jej existencii nachádzame nepriame zmienky aj v historických prameňoch, z ktorých vyplýva, že pred rokom 1575 došlo k výstavbe dreveného opevnenia Dobronivského hradu (Maliniak 2014a, 60). Na základe pozorovatel'ných antropogénnych reliktov na terasách obklopujúcich hradné jadro je zrejmé, že opevnenie hradu pozostávalo okrem palisády z hlbokej priekopy, ktorá mohla byt' na niektorých miestach aj zdvojená. Samotná vstupná brána bola pritom pravdepodobne murovaná, čo naznačuje tu zachované torzo. Silné uhlíkové vrstvy pozorované v profiloch v okolí a na dne palisády vypovedajú o jej katastrofickom zániku.

Výsledky archeologického výskumu spresnili údaje aj o chronológii osídlenia celého hradného kopca. Najstaršie keramické nálezy objavené v predhradí pochádzajú z praveku. Niektoré črepy pripomínajú keramiku badenského/postbadenského obdobia, známu z okolitých nálezísk (Pustý hrad, poloha Dolný hrad; Lieskovec, poloha Hrádok; Beljak a kol. 2014, 80-98), avšak pravdepodobnejšie je osídlenie lokality v mladšej a neskorej dobe bronzovej.

Mimoriadne významné sú objavené keramické nálezy z neskorého (15. storočie) a vrcholného (13.-14. storočie; obr. 9:11) stredoveku. Hoci ide o horizonty osídlenia zachytené len prostredníctvom menšieho súboru, nálezy korešpondujú s obdobím samotnej výstavby a prvotných úprav hradu.

Najpočetnejšie (variabilnými tvarmi renesančnej keramiky) je v areáli hradu zastúpený horizont 16.-17. storočia. Len v malej miere bola na nádvorí zastúpená mladonovoveká keramika, ktorá reprezentuje bežný spotrebný riad používaný ešte v 18. storočí. Znamená to teda, že v tomto období už hrad nebol funkčným objektom.

K najvýznamnejším novovekým objavom na nádvorí patrili napr. strieborný denár Žigmunda Luxemburského (obr. 9:1), hlavica sústruženej (?) kostenej zdobenej ihlice (obr. 9:4), rytím zdobené kostené obloženie (obr. 9:6) rukoväte (?), kostený nuncius z kuše (obr. 9:3), krehký dlhší vyhladený kostený predmet s očkom (obr. 9:5), liate kovanie ozdobného opasku (obr. 9:2), kovová zdobená zápona knižného kovania (obr. 9:9), vegetabilným ornamentom zdobené plechové koncové kovanie pošvy šable/dýky (obr. 9:8), reliéfne zdobený zlomok z čelnej vyhrievacej steny datovaný na prelom 15. a 16. storočia (obr. 9:7), misa s tzv. tanierovitým podokrajom na engobe a s výzdobou kukučky pod transparentnou glazúrou žltej farby zo 17. storočia (obr. 9:10).

Početný nálezový materiál získaný z predhradia je značne fragmentárny a poukazuje na sčasti bežný kuchynský odpad. Viaceré nálezy boli však opálené, teda podrobené žiaru a mnohé sa zachovali aj vo väčších zlomkoch. Objavený súbor materiálnej kultúry vypovedá o náhlom zasypaní priestoru a o ich dobrom uchovaní v podpovrchových vrstvách, kde boli uchránené pred poveternostnými podmienkami. Je evidentné, že až do ich objavenia (počas nami realizovaného výskumu) s nimi nikto nemanipuloval. Keramiku, rovnako ako objavené kovové predmety na 

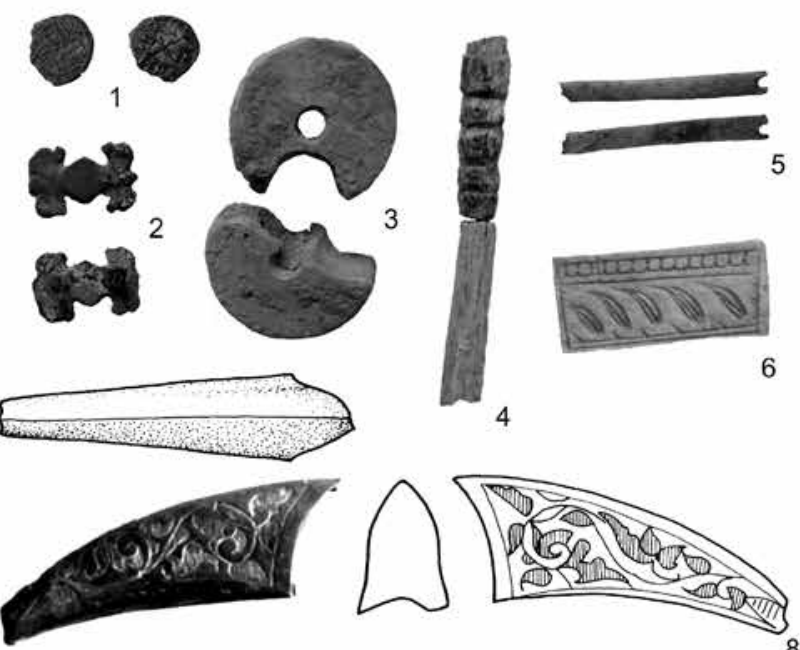

6

4
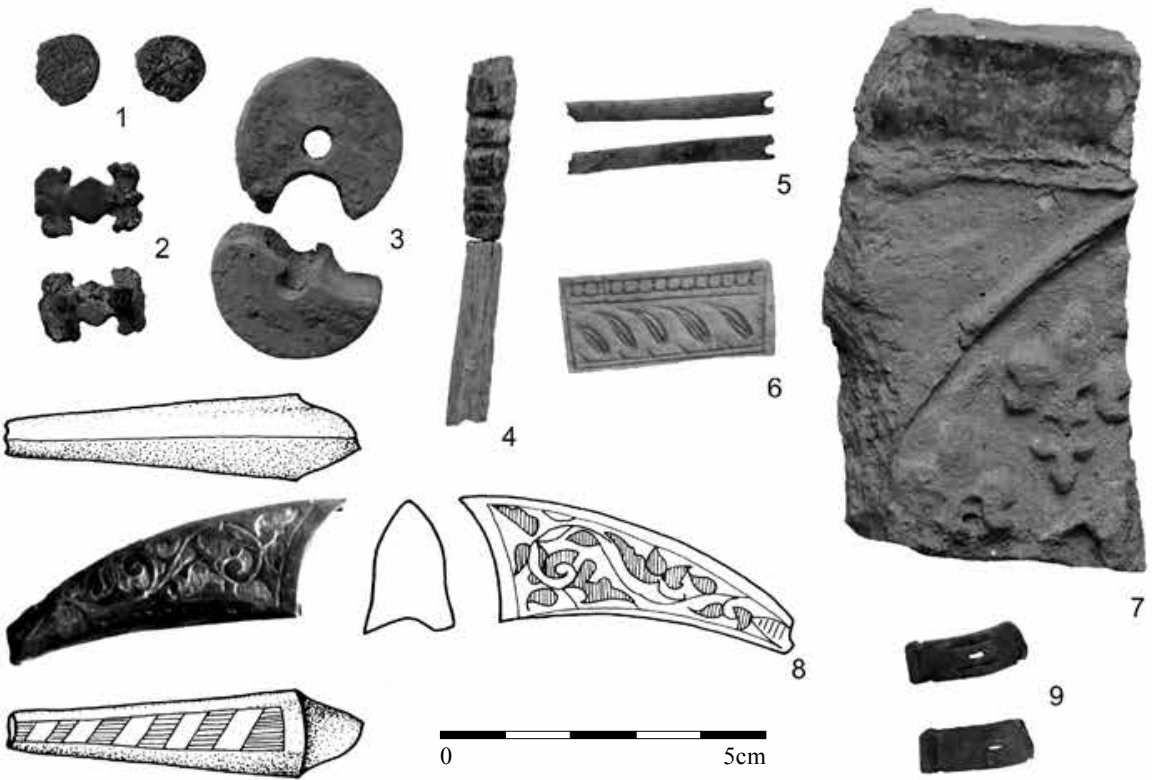

9
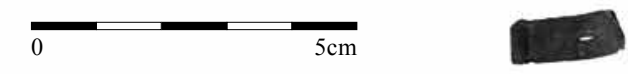

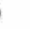
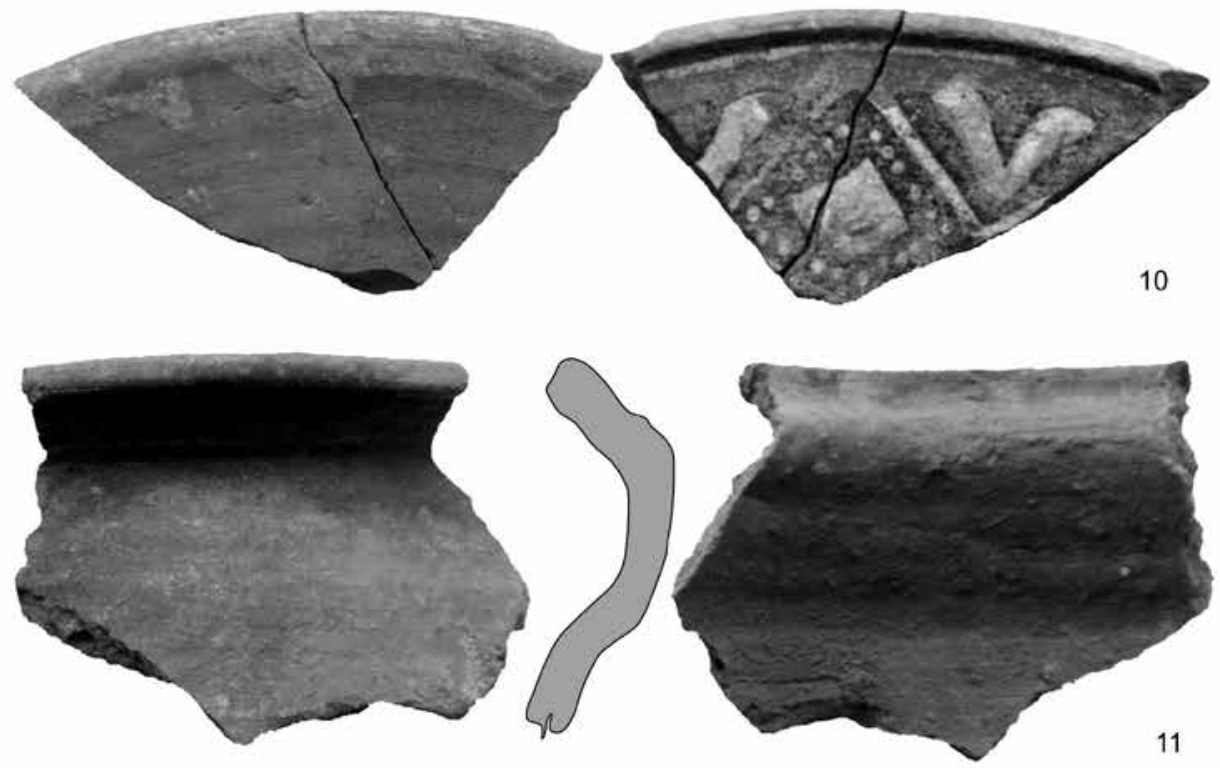

Obr. 9. Hrad Dobrá Niva, okr. Zvolen. Predhradie - sondy 2/2013 (4-11) a 1/2014 (1-3). Výber nálezov.

Abb. 9. Burg Döbring, Bezirk Zvolen. Vorburg - Sondierschnitt 2/2013 (4-11) und 1/2014 (1-3). Auswahl an Funden.

nádvorí hradu, považujeme aj z tohto dôvodu za spolahlivý datovací materiál existencie a zániku hradu. Výraznú prevahu v súbore majú jednoznačne nádoby vysokých tvarov - džbány a hrnce na bočný ohrev, čo naznačuje aj očadenie na vonkajšej strane. Bohato zastúpené boli aj misovité tvary, poháre a pokrievky. Získaná materiálna kultúra (keramika, kachlice, kovové nálezy, zvieracie kosti) je v súčasnosti spracovávaná a jednotlivé celky budú vyhodnotené v samo- 
statných príspevkoch, ktoré prinesú d'alšie odpovede na chronologické otázky, ako aj informácie o využití hradného areálu, resp. o každodennom živote na hrade.

Výskum na hrade Dobrá Niva je v súčasnosti ukončený a archeologické sondy boli zasypané. V budúcnosti však nevylučujeme jeho opätovné skúmanie. Vhodný a zo stavebno-historického hladiska určite prínosný by bol výskum v priestore vstupnej brány hradu. Na jej predpokladanom mieste sú aj v súčasnosti ešte viditel'né deštrukcie kamenného muriva.

Príspevok vznikol v rámci riešenia projektu Vedeckej grantovej agentúry Ministerstva školstva, vedy, výskumu a športu Slovenskej republiky a Slovenskej akadémie vied (VEGA) číslo 1/0208/15 Človek a hory $\mathrm{v}$ priebehu času - od pravekých hradísk k stredovekým hradom.

\section{Literatúra}

BELJAK, J., a kol., 2014: Pustý hrad vo Zvolene. Dolný hrad 2009-2014. Zvolen - Nitra.

BELJAK, J.-PAŽINOVÁ, N., 2014: Praveké a stredoveké osídlenie z pohladu archeológie. In: Dobrá Niva. Monografia obce (Očenášová-Štrbová, S., ed.), 45-52. Dobrá Niva.

GINDL, J., 1967: Význam zvolensko-dobronivského panstva pre stredoslovenské baníctvo. In: Historický zborník kraja III, 331-336. Banská Bystrica.

JANŠÁK, Š., 1930: Staré osídlenie Slovenska, Sborník muzeálnej Slovenskej spoločnosti XXIV, 60-61.

KNAUZ, N.-NAGY, I., edd., 1862: Eszterházy Sándor Urbariuma Anno 1668. Magyar Tudományos Értekező. II. köt., V és VI füz. (Ifj. Kubinyi, F., ed.), 466-467. Budapest.

KOPČAN, V.-KRAJČOVIČOVÁ, K., 1983: Slovensko v tieni polmesiaca. Martin.

KUBÍNYI, F., 1859: Zólyommegye müemlékei, Arch. Közlemények I, 17-46.

MÁCELOVÁ, M., 1990: Stredoveký sídliskový objekt v Dubovom, Archeologické výskumy a nálezy v roku $1988,108$.

MALINIAK, P., 2014: Stredoveké mestečko a jeho obyvatelia. In: Dobrá Niva. Monografia obce (Očenášová-Štrbová, S., ed.), 53-58. Dobrá Niva.

- 2014a: Z histórie v ranom novoveku. In: Dobrá Niva. Monografia obce (Očenášová-Štrbová, S., ed.), 59-66. Dobrá Niva.

PLAČEK, M.-BÓNA, M., 2007: Encyklopédia slovenských hradov. Bratislava.

SLÁVIK, J., 1898: Dejiny dobronivskej evanjelickej cirkve, niektoré dávnejšie deje královského výsadného mestečka Dobronivej a okolia. Ružomberok.

ZÁVADOVÁ, K., 1974: Verný a pravý obraz slovenských miest a hradov, ako ich znázornili rytci a ilustrátori v XVI., XVII. a XVIII. storočí. Bratislava.

\section{Zusammenfassung}

\section{Die Grabungen auf Burg Döbring (Dobrá Niva) in den Jahren 2013 und 2014}

Die im Bezirk Zvolen liegende Gemeinde Dobrá Niva (Döbring) befindet sich in der Mittelslowakei im Mittelteil des Talkessels Pliešovská kotlina. Die erste schriftliche Erwähnung der Gemeinde Dobrá Niva stammt von König Béla IV. aus dem Jahr 1254. Die nicht ganz 3 km Luftlinie in nördlicher Richtung von der Gemeinde auf einer konischen Anhöhe entfernt gelegene Burg (Abb. 1, 2) findet erstmals in Urkunden aus dem Jahr 1306 Erwähnung, als die vorrückende Armee des ungarischen Königs Karl I. Robert die Döbringer Burg zusammen mit weiteren Festungen des Altsohler Komitatsgrafen Demeter eroberte (Maliniak 2014, 54). Die Ruine gehört zum Kataster der Gemeinde Podzámčok, die sich aus einem Gehöft unterhalb der Burg entwickelte. Die Burg Döbring wurde 1963 zum nationalen Kulturdenkmal erklärt (Zentralliste der Denkmäler in der Slowakei Nr. 1110/1).

Die Forschungsaktivitäten auf der Burg konzentrierten sich auf das Jahr 2013, als die Grabungen vom Archäologischen Institut der Slowakischen Akademie der Wissenschaften durchgeführt wurden, ferner auf das Jahr 2014, als die archäologische Untersuchung unter der Leitung 
des Lehrstuhls für Archäologie der Philosophischen Fakultät der Konstantin der Philosophe Universität in Nitra erfolgte. Die bauhistorische Auswertung der freigelegten Gemäuer wurde von M. Šimkovic ausgearbeitet.

Ziel der Grabungen war es, die bauliche Anlage und Entwicklung des Burgpalas hinsichtlich seiner Konstruktion in Erfahrung zu bringen, ferner wie die Vorburg im Laufe der Zeit genutzt wurde und funktionell gegliedert war, und zwar sowohl zu Siedlungszwecken, als auch zu weiteren Verteidigungs- bzw. Produktionsaktivitäten. Auf der Burg wurde eine zerstörungsfreie Untersuchung in Form von Luftbildern sowie eine geophysikalische Untersuchung durchgeführt. Sondiergrabungen erfolgten in der Kernburg (Sondierschnitt 1/2013) und in der Vorburg (Sondierschnitte 2/2013, 1/2014 und 1A/2014). Die untersuchte Gesamtfläche betrug $24 \mathrm{~m}^{2}$. Es wurde nachgewiesen, dass der Burgpalas einen sechseckigen Grundriss hatte. Auch ist es gelungen, die älteste, bis ins 14. Jahrhundert zurückreichende Bauphase zu erfassen, wobei nicht ausgeschlossen ist, dass es sich dabei um das Mauerwerk des ursprünglichen Palas handelt (Abb. 3, 4). Im östlichen Teil der Vorburg konnte durch die archäologische Grabung der Verlauf der Palisadenbefestigung des Areals nachgewiesen und dokumentiert werden (Abb. 5-8). Sein Bau setzte eine gezielte Herrichtung des Geländes voraus, die daraus bestand, einen Felsen durch Behauen abzutragen und anschließend zu ebnen. Der entstandene Raum wurde mit festem gelb-braunen Lehm aufgefüllt, in den die mächtige Palisade gesetzt wurde. Die starken Holzkohleschichten in den Profilen der Umgebung und am Boden der Palisade zeugen davon, dass sie durch eine Katastrophe unterging. Aufgrund der feststellbaren anthropogenen Relikten auf den die Kernburg umgebenden Terrassen ist es offensichtlich, dass die Befestigung der Burg neben der Palisade noch aus einem tiefen Graben bestand, der an einigen Stellen auch doppelt vorhanden gewesen sein könnte. Das Eingangstor selbst war dabei wahrscheinlich gemauert, was durch den erhaltenen Torso eines Mauerwerks angedeutet wird.

Die Ergebnisse der archäologischen Grabungen haben auch die Angaben über die Chronologie der Besiedelung des gesamten Burghügels präzisiert. Die ältesten in der Vorburg entdeckten Keramikfunde stammen aus der Urzeit. Von außerordentlicher Bedeutung sind die gemachten Keramikfunde aus dem Spät- (15. Jhdt.) und Hochmittelalter (13.-14. Jhdt.; Abb. 9:11). Auf dem Burgareal am zahlreichsten vertreten ist der Horizont des 16.-17. Jahrhunderts (Abb. 9:1-10). Nur in geringem Maße vertreten war jungneuzeitliche Keramik im Hof, die gängiges, noch im 18. Jahrhundert verwendes Gebrauchsgeschirr repräsentierte. Das bedeutet also, dass die Burg in diesem Zeitraum bereits kein funktionierendes Objekt mehr war.

Der vorliegende Beitrag entstand im Rahmen des Projekts der Wissenschaftlichen Förderagentur des Ministeriums für Schulwesen, Wissenschaft, Forschung und Sport der Republik Slowakei und der Slowakischen Akademie der Wissenschaften (VEGA) Nr. 1/0208/15 Der Mensch und die Berge im Verlauf der Zeit - von den urzeitlichen Burgwällen bis zu den Burgen des Mittelalters.

doc. PhDr. Noémi Beljak Pažinová, PhD., Katedra archeológie Filozofickej fakulty Univerzity Konštantína Filozofa v Nitre, Hodžova 1, SK 94901 Nitra, Slovenská republika, nbpazinova@ukf.sk

PhDr. Ján Beljak, PhD., Archeologický ústav SAV, výskumné pracovisko Zvolen, Štúrova 2, SK 96001 Zvolen, Slovenská republika, beljak@sav.savzv.sk

Mgr. Michal Šimkovic, Mgr. Michal Šimkovic s.r.o., Kimovská 2341/4, SK 96001 Zvolen, Slovenská republika, simkovic.miso@gmail.com 
